\title{
Weighted Linear Combination Procedures with GIS and Remote Sensing in Flood Vulnerability Analysis of Abeokuta Metropolis in Nigeria
}

\author{
Oyedepo J. A. ${ }^{1, *}$, Adegboyega J. ${ }^{2}$, Oluyege D. E. ${ }^{3}$, and Babajide, E. I. ${ }^{4}$ \\ 1,3,4 Institute of Food Security, Environmental Resources and Agricultural Research, Federal University of \\ Agriculture, Abeokuta, Nigeria \\ ${ }^{2}$ Department of Environmental Management and Toxicology, College of Environmental Resources \\ Management, Federal University of Agriculture, Abeokuta, Nigeria \\ Corresponding Author: *oyedepoja @ fuaab.edu.ng
}

https://doi.org/10.36263/nijest. 2021.01.0260

\begin{abstract}
The study offered the opportunity for an evaluation of the role of Remote Sensing and Geospatial techniques in flood disaster risk management and development of spatial decision support system for flood risk assessment and management in Abeokuta metropolis. Datasets used includes cloud free high resolution satellite images and Shuttle Radar Topographic Mission (SRTM) data downloaded from earth explorer site. Soil data used was obtained from Food and Agriculture Organization (FAO's) Harmonised World Soil Database, while rainfall data was obtained from the Climate Hazards Group InfraRed Precipitation Station. Maps of flood enhancing factors namely: soil types, rainfall intensity, drainage density and topography were created in Geographic Information Systems using same scale of 1: 50,000 and Geographic coordinate system (WGS 1984). All maps were produced in raster format with the same cell grid cell size of $0.0028 \mathrm{~mm}$. They were then subjected to weighting by ranking and Multi-Criteria Analysis (MCA) using the Weighted Linear Combination. The study identified topography and land use as key factors contributing to flooding within Abeokuta metropolis. Obstruction of natural drainage channels by buildings aggravates disasters from flash flood events.
\end{abstract}

Keywords: Flash flooding, Flood Vulnerability, GIS-Remote sensing model, Weighted Linear combination, Multi-Criteria Evaluation, Abeokuta Metropolis

\subsection{Introduction}

Inundations from runoffs and river overflows have become a frequent occurrence in many urban areas of the world (Tanoue et al., 2016; Egbinola et al., 2017; Cirella and Iyalomhe, 2018; Zorn, 2018; Rubinato et al., 2019). Floods have affected more than 2.8 billion people in the world and caused more than 200,000 deaths in the last thirty years (BBC News, 2018; Olanrewaju et al., 2019). Greater percentages of recent global fatalities in cities have been associated with flood-induced events (Hong et al., 2018; Hu et al., 2018; Špitalar et al., 2020). This supports the claim that flooding accounts for $47 \%$ of weather-related disasters world-wide (UNISDR, 2015).

Available records in Nigeria indicate devastating urban flood events in several cities in the two decades (Olawuni et al., 2015). Floodlist (2020) documented close to four dozens of flood incidents that have occurred across Nigeria in the last thirty-five years. These events include Ibadan floods of years 1985, 1987, 1990, and 2011; Osogbo floods of years 1992, 1996, 2002, and 2010; Yobe flood of year 2000 and Akure flood of years 1996, 2000, 2002, 2004 and 2006. For other locations such as Lagos, Abeokuta, Benin, Port Harcourt, Calabar, Uyo and Warri to list a few, authors like Ogbonna et al., (2011), Aderogba (2012), Efobi (2013), Ogundele and Ubaekwe (2019) and Echendu (2020) reported flooding as a disaster of immense ecological and socio-economic impacts. Abeokuta metropolis for instance witnessed flash floods that swept people and properties off at specific locations in the years 2012, 2016, 2018, and 2020. Ogunaike (2020) reported flood disasters within the metropolis in places like Igbore, Gbangba, Abiola way, Ijaye, Oke-Ejigbo, Isale Abese Obantoko 
and Opako Oke Lantoro, Iyana-Amolaso, Lafenwa, Ijaiye, Totoro, Kuto and Kobiti. The city flash flood of year 2020 was particularly recounted to destroy public and private buildings in many areas in the metropolis.

As efforts to reduce the frequency of occurrence and lessen impacts of flood disasters in many susceptible areas intensify, more methods of flood vulnerability and flood risks assessments have emerged over the decades (Perera et al., 2019; Martinez et al., 2021). Flood risk evaluation or vulnerability assessment has been described as the proactive steps for preventing flood disasters and to provide guidance for mitigation decisions (MRC, 2016; Tascón-González et al., 2020). According to Wang et al. (2011), there are two broad categories of methodologies for flood risk assessments namely; quantitative and qualitative approaches. The quantitative method estimates the magnitude of expected losses to flood with existing numerical data, while qualitative procedures examines a combination factors can influence the chances of occurrence of flood. The qualitative technics invariably combines flood risk indicators using ranking and weighting to determine relative levels of vulnerabilities of a given area to flooding (Dewan, 2013; Nkeki et al., 2013; Umaru and Adedokun, 2020). Nasiri et al. (2016) further separated the two broad methods into four most frequently used methods of flood risk analysis which includes; vulnerability index system, vulnerability curve, disaster loss data and computer models. According to Wang et al. (2011), vulnerability curve and disaster loss data qualify as quantitative methods; since they rely on availability of previous flood statistics, while vulnerability index systems and computer modelling can be grouped as qualitative techniques.

The demerits and merits of these methods are often considered before adopting any of them for particular flood risk assessment case. Quantitative methods of flood vulnerability assessment could sometimes give superior results where there are accurate and reliable data and statistics of previous flood events. This also implies that the method is limited by data availability and accuracy. Vulnerability curve method for instance, can be used to relate the flood risk and the elements at risk through realistic damage curves (Nasiri et al., 2019). This is however; greatly dependent on reliable empirical cases, the limitation of the method is greatly highlighted with paucity of numerical and comprehensive morphological data (Halgamuge and Nirmalathas, 2017). More frequently, actual damage survey is required and this is not only time and resource consuming, but its reliability is less than others because the data is location specific and cannot be applied for other geographic locations. Similarly, Disaster-loss method is premised on data obtained from real flood hazard, although it is a relatively very simple approach and can be used to predict imminent flood events, but its major demerit is in its inaccuracy due to disproportionately chronicled data (Nazeer and Bork, 2019). Its results are usually taken with great caution.

Modeling methods however include the combination of a number of factors that can influence flooding to create vulnerability scenarios (Djimesah et al., 2018; Komolafe et al., 2020). Often computer programming is employed in modelling of flood vulnerability. A very common example of flood vulnerability modelling includes the use of multi-criteria evaluation (MCE) or convolutional neural network (CNN) analysis within a Geographical Information System (GIS) and satellite remote sensing environment (Wang et al., 2011; Wang et al., 2019). When factors like channel parameters, flood velocity, terrain and relief (elevations and depression) and hydrologic data of an area are combined in GIS environment to create flood scenarios, the model is described as multi-criteria evaluation (Tzioutzios and Kastridis, 2020). Various multi-criteria evaluation (MCE) techniques have been used for flood susceptibility and vulnerability analysis and risk mapping with very good accuracy levels (Elsheikh et al., 2015; Fernandez et al., 2016; Rimba et al., 2017). A mode of MCE is the weighted linear combination procedures (WLC) in a GIS environment (Morales and de Vries, 2021). The weighted linear combination (WLC) procedure is one of the widely used multicriteria decision-making tools. One great merit of WLC procedure above other methods is its provision of spatial decision-support tool in analyzing environmental problems such as flood (Siddayao et al., 2014). The method can rank multiple alternatives, on the basis of several criteria that may have different units and evaluate their respective consequences (Mahmoody and JelokhaniNiaraki, 2021). The method also does not depend on availability of previous or actual flood data. It is a much cheaper and faster method of vulnerability analysis since it relies on environmental parameters such as soil types, rainfall intensities, relief (topographical data) which are readily available (Wang et al., 2011; Chen et al., 2014). Beyond these, WLC procedures is quite simple to 
implement and interpret, it is also capable in handling poor quality can be efficiently applied in any region since it is not limited by geographical locations.

In this paper, combination of weighted linear procedures with GIS and remote sensing was employed to combine heterogeneous flood inducing environmental factors and spatial data to determine the relative susceptibility of different parts of Abeokuta city to flooding.

\subsection{Materials and method}

\subsection{The study area}

Abeokuta metropolis; one of the capital cities in Southwest Nigeria with a population of 593,140 spread over 125,600 hectares of land (Population Stat, 2020). The city lies between Latitudes, $7^{0} 5^{\prime} \mathrm{N}$ and $7^{0} 20^{\prime} \mathrm{E}$ and between Longitudes, $3^{0} 17^{\prime} \mathrm{E}$ and $7^{\circ} 27^{\prime} \mathrm{E}$. The geology is crystalline pre-Cambrian basement complex with outcrops of igneous and metamorphic rocks visible in different parts of the conurbation. The city has a mesh of streams all draining into the Ogun River. The yearly annual releases from the Oyan and Ikere gorge Dams makes the inland valleys of the river which has been encroached by residential buildings to become heavily flooded at the peak of the rains (Sobowale and Oyedepo, 2013). Abeokuta portrays the geology of an underlying basement complex of Precambrian origin which predisposes it to poor water percolations (Akinse and Gbadebo, 2016). The city metropolis also has a convoluted drainage networks made up of dendrite rivulets; all draining into one long tortuous Ogun River that runs into Lagos lagoon. These unique peculiarities of the Abeokuta city make it vulnerable to flooding at the in-land valleys and flood plains of the rivulets which incidentally are been encroached by residential buildings.

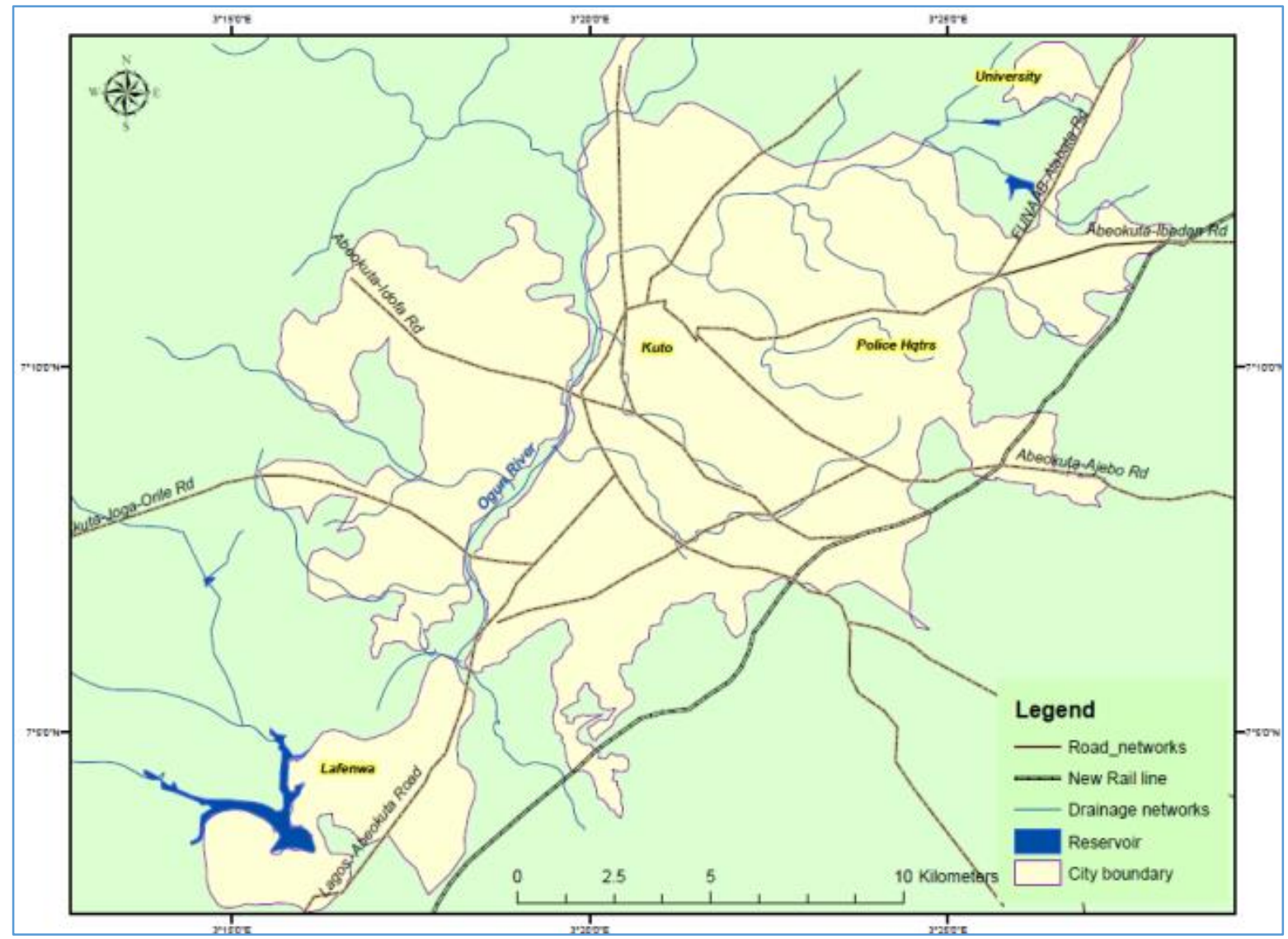

Figure 1: Map of Abeokuta Metropolis

\subsection{Data collection and data analysis}

Data from both primary and secondary sources were used for the study. The primary data include field measurements such as river channel width and depth and stream flow rate (velocity). Stream flow rate and channel metrics (width and depth) were taken from 3 main points namely: Ita Eko River, Ogun River and Arakanga River. The lengths of the various streams from the satellite image were 
determined in a GIS environment. The other points were from rivulets and tributary to Ogun River namely: Apete, Ole and Apakila. Secondary data includes: soil types obtained from Harmonized World Soil Data Base (HWSD), Satellite image of drainage networks of the city, the land use/ land cover data, Digital Elevation Model obtained from Shuttle Radar Topographic Missions (SRTM) and rainfall data obtained from Climate Hazards Group InfraRed Precipitation with Station data (CHIRPS).

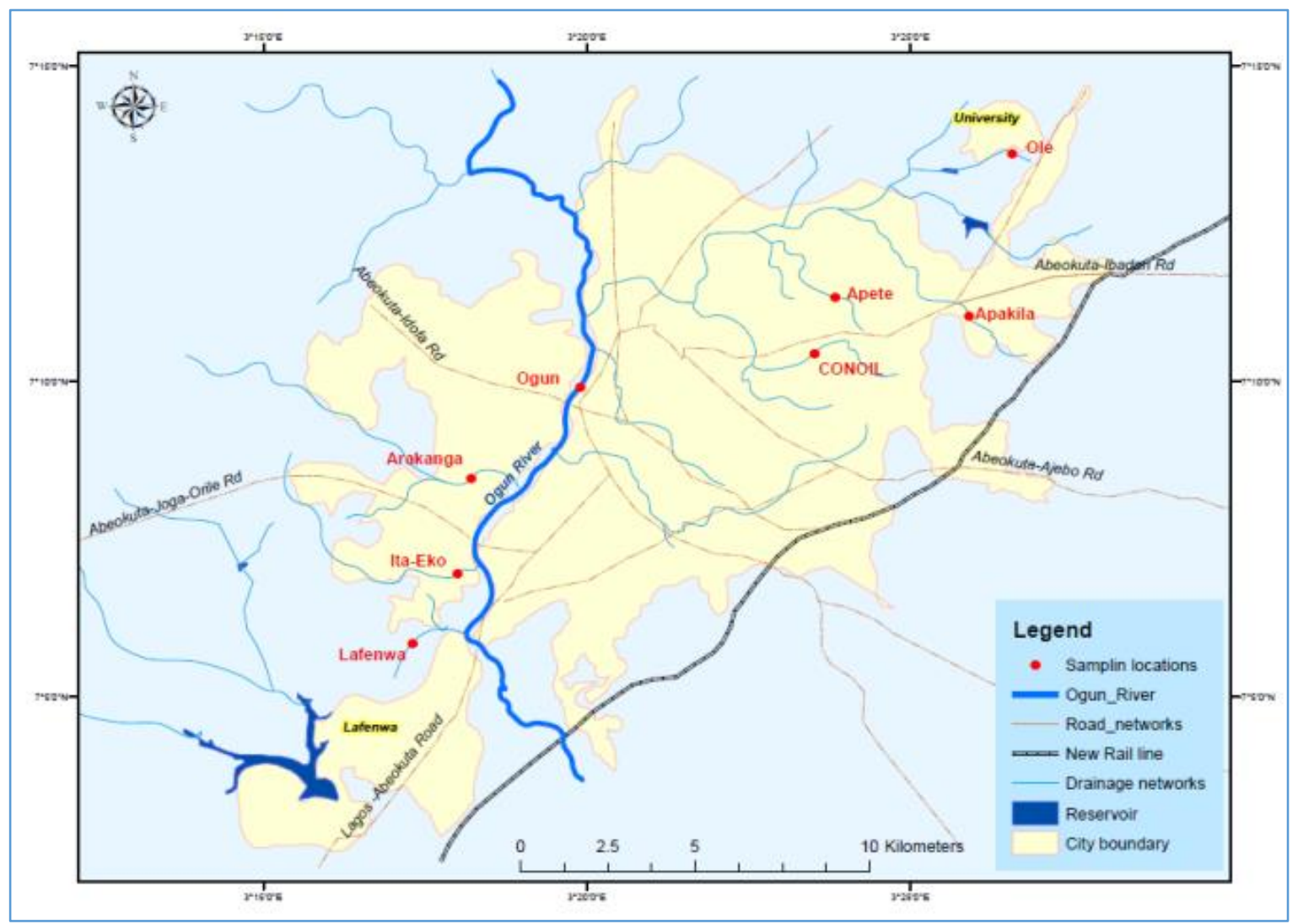

Figure 2: Map showing sampling locations

The reliability of satellite-derived meteorological data has been tested in very recent past with very positive outcomes. Akinyemi et al. (2020) compared satellite-derived rainfall records namely; CHIRPS, TRIMM and RFE data for six locations in South-west Nigeria with records from NIMET ground stations in order to ascertain the reliability of satellite derived data. The authors reported very high positive correlation values as presented in Table 1.

Table 1: Correlation values $\left(\mathrm{R}^{2}\right)$ of NIMET, with TRMM, CHIRPS and RFE data

\begin{tabular}{lccc}
\hline Locations & TRMM/NIMET & CHIRPS/NIMET & RFE/NIMET \\
\hline Abeokuta & 0.985 & 0.961 & 0.897 \\
Ado-Ekiti & 0.821 & 0.775 & 0.892 \\
Akure & 0.979 & 0.995 & 0.894 \\
Ikeja & 0.782 & 0.85 & 0.844 \\
Oshogbo & 0.98 & 0.979 & 0.927 \\
Ibadan & 0.801 & 0.807 & 0.854 \\
\hline \multicolumn{4}{c}{ Source: Akinyemi et al. $(2020)$}
\end{tabular}

The data set used by the authors in Table 1 namely; Tropical Rainfall Measuring Mission (TRMM), Climate Hazards Group Infrared Precipitation with Stations (CHIRPS) and African Rainfall Estimation (RFE 2.0), which were obtained from the archives of the NOAA Climate Prediction Centre while the ground meteorological data were obtained from the Nigerian Meteorological Agency (NIMET), Oshodi in Lagos.

The high positive correlation value of 0.985 in comparison of CHIRPS with NIMET ascertains the reliability of the data for this study. 
Landsat TM 8 acquired in year 2019 downloaded from United State Geological Survey USGS geoportal (Earth explorer) was georeferenced and the drainage networks of the city were digitized from it. Soil data was also acquired from Food and Agriculture Organization FAO Harmonized World Soil Data base. The Shuttle Radar Topographic Mission was used to produce the Digital Elevation Model (DEM) from which terrain modelling and hydrological analysis of the area was done.

\subsection{Data processing, integration and spatial analysis}

The primary data collected from the field (soil type, flow rate, channel metrics) were all collated and analysed using the Statistical Package for Social Scientists (SPSS). Maps of all contributing factors to flash flood namely: soil types, meteorology, drainage density and topography were created in ArcMap using same scale of 1: 50,000 and Geographic coordinate system (WGS 1984). All maps were ensured to be in raster format with the same cell grid cell size of $0.0028 \mathrm{~mm}$. They were then subjected to weighting by ranking and Multi-Criteria Analysis (MCA) using the "Weighted Linear Combination" (WLC) method (Moeinaddini et al., 2010; Al-Hanbali et al., 2011).

For the weighting by ranking to be performed, each data was reclassified into five groups of 1 to 5 as shown in the Table 2.

Table 2: Ranking for factors of flooding

$\begin{array}{cl} & \text { Not vulnerable } \\ & \text { Less vulnerable } \\ & \text { Moderately vulnerable } \\ & \text { More vulnerable } \\ \text { Most vulnerable }\end{array}$

In order to find the percentage influence of each contributing factors, weighting factors were attached to each layer of raster data as shown in the Table 3.

Table 3: Weighting of each factor associated with flooding

\begin{tabular}{ll}
\hline Criteria & Percentage of influence \\
\hline Landuse & $20 \%$ \\
Rainfall & $25 \%$ \\
Elevation & $10 \%$ \\
Slope degree & $15 \%$ \\
Soil drainage & $20 \%$ \\
Drainage Density & $10 \%$ \\
\hline Total & $100 \%$ \\
\hline
\end{tabular}

The contributing factor with the highest influence to flash flooding is rainfall with a score of $25 \%$. Table 4 presents the weighting and ranking of all contributing factors to flash flooding.

\subsection{RESULTS AND DISCUSSION}

\subsection{Contributing factors to flood vulnerability in Abeokuta}

Increased run-offs which is a direct effect of rainfall intensity often leads to channel overflow and the persistence of any overflow in an environment is a function of its topographical characteristics and soil permeability. The volume of the run offs and severity of flood also depends on drainage intensity, land use pattern.

In this study, a simple linear combination of the various factors of flooding namely; rainfall intensity, soil types, topography, natural drainage density and land use pattern was done and their relative contributions are ranked by attaching some weighting factors as described in Multi-Criteria Analysis procedures. Since spatial technologies particularly GIS is employed as an analytical tool, most of the results are presented graphically in map form. 


\section{a. Flood vulnerability by rainfall intensity}

The map shown in Figure 3 is the mean rainfall from March to October over Abeokuta region which has been spatially range into five categories namely; (a) 170 to $176 \mathrm{~mm}$, (b) 177 to $181 \mathrm{~mm}$, (c) 182 to $186 \mathrm{~mm}$ (d) 187 and $191 \mathrm{~mm}$ and (e) areas with rainfall above 192 to $199 \mathrm{~mm}$.

Table 4: Weighting and ranking of all factors associated with flood vulnerability

\begin{tabular}{|c|c|c|c|}
\hline Criteria & Class & Ranking & Weight \\
\hline \multirow[t]{4}{*}{ Soil } & Dystric Nitosols (Well drained) & 1 (Not vulnerable) & $20 \%$ \\
\hline & Lithosols (Moderately drained) & 3 (Moderately vulnerable) & \\
\hline & Ferric Luvisols (Imperfectly drained) & 4 (More vulnerable) & \\
\hline & Pellic Vertisols (Poorly drained) & 5 (Most vulnerable) & \\
\hline \multirow[t]{5}{*}{ Elevation } & $<50$ & 5 (Most vulnerable) & $10 \%$ \\
\hline & $50-130$ & 4 (More vulnerable) & \\
\hline & $130-217$ & 3 (Moderately vulnerable) & \\
\hline & 217-331 & 2 (Less Vulnerable) & \\
\hline & $>331$ & 1 (Not vulnerable) & \\
\hline Slope & $0-1$ & 5 (Most vulnerable) & $15 \%$ \\
\hline \multirow[t]{4}{*}{ degree } & $2-3$ & 4 (More vulnerable) & \\
\hline & $4-4$ & 3 (Moderately vulnerable) & \\
\hline & $5-7$ & 2 (Less Vulnerable) & \\
\hline & $8-19$ & 1 (Not vulnerable) & \\
\hline Drainage & $<0.002$ & 1 (Not vulnerable) & $10 \%$ \\
\hline \multirow[t]{4}{*}{ Density } & $0.003-0.003$ & 2 (Less Vulnerable) & \\
\hline & $0.004-0.005$ & 3 (Moderately vulnerable) & \\
\hline & $0.006-0.007$ & 4 (More vulnerable) & \\
\hline & $0.008-0.008$ & 5 (Most vulnerable) & \\
\hline Mean & $170-176$ & 1 (Not vulnerable) & $25 \%$ \\
\hline \multirow{4}{*}{ Rainfall } & $177-181$ & 2 (Less Vulnerable) & \\
\hline & $182-186$ & 3 (Moderately vulnerable) & \\
\hline & $187-191$ & 4 (More vulnerable) & \\
\hline & $192-199$ & 5 (Most vulnerable) & \\
\hline \multirow{4}{*}{ Land use } & Built up & 5 (Most vulnerable) & $20 \%$ \\
\hline & Bare land & 4 (More vulnerable) & \\
\hline & Grassland & 3 (Moderately vulnerable) & \\
\hline & Intensive row crop rain-fed agriculture & 2 (Less Vulnerable) & \\
\hline Total & & & $100 \%$ \\
\hline
\end{tabular}

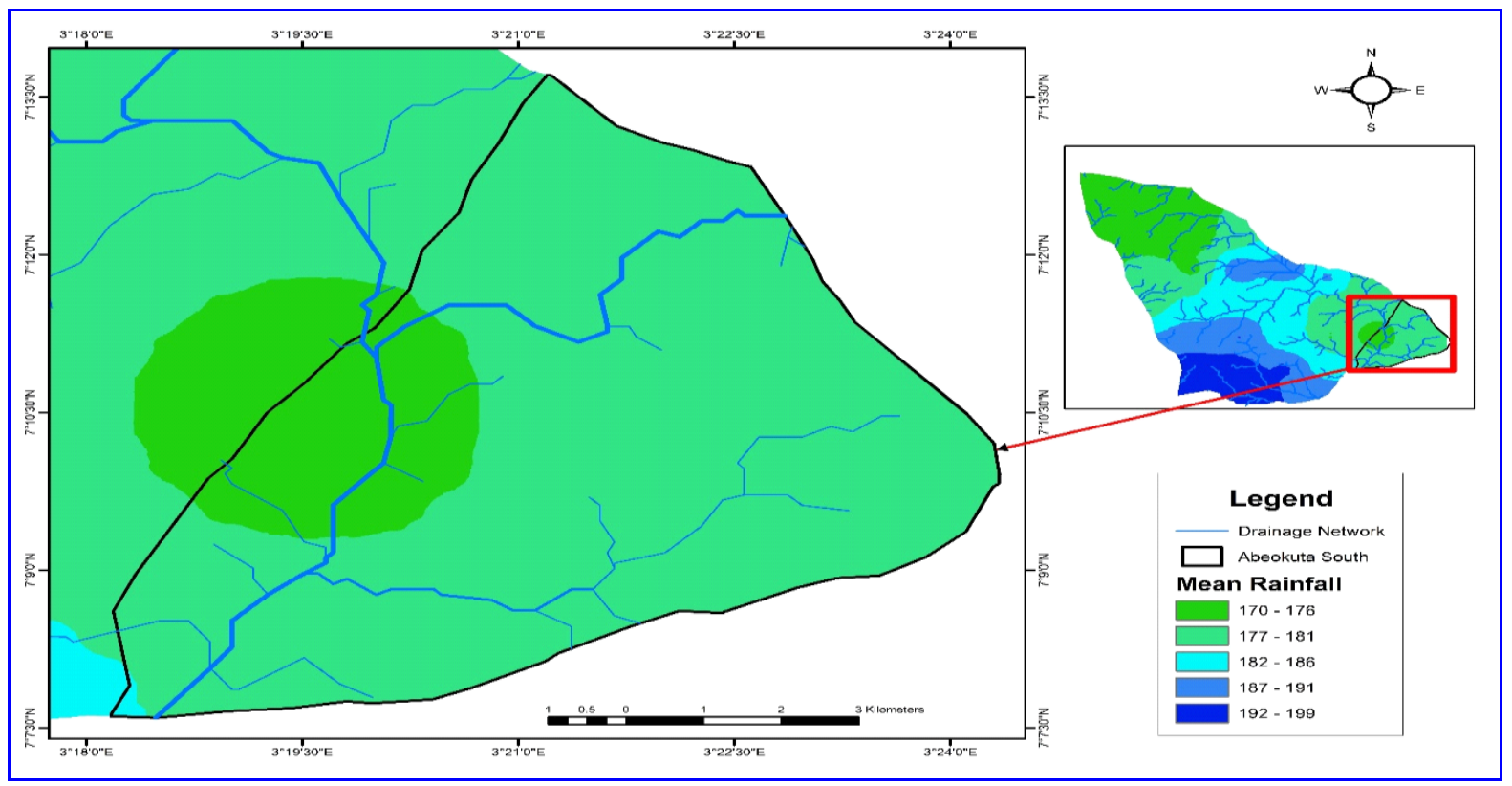

Figure 3: Mean rainfall over Abeokuta metropolis (inset: Abeokuta region).

The area occupied by the metropolis (left inset) has rainfall range of 170 to $181 \mathrm{~mm}$ which is the lowest mean annual rainfall. This implies that relative influence of rainfall intensity on area occupied by the metropolis with regards to flooding is lowest in the region. However, ranking the map in figure 4 by assigning weights and Multi-Criteria Analysis gives better insights to flood vulnerability by rainfall intensity as shown in Figure 4. 


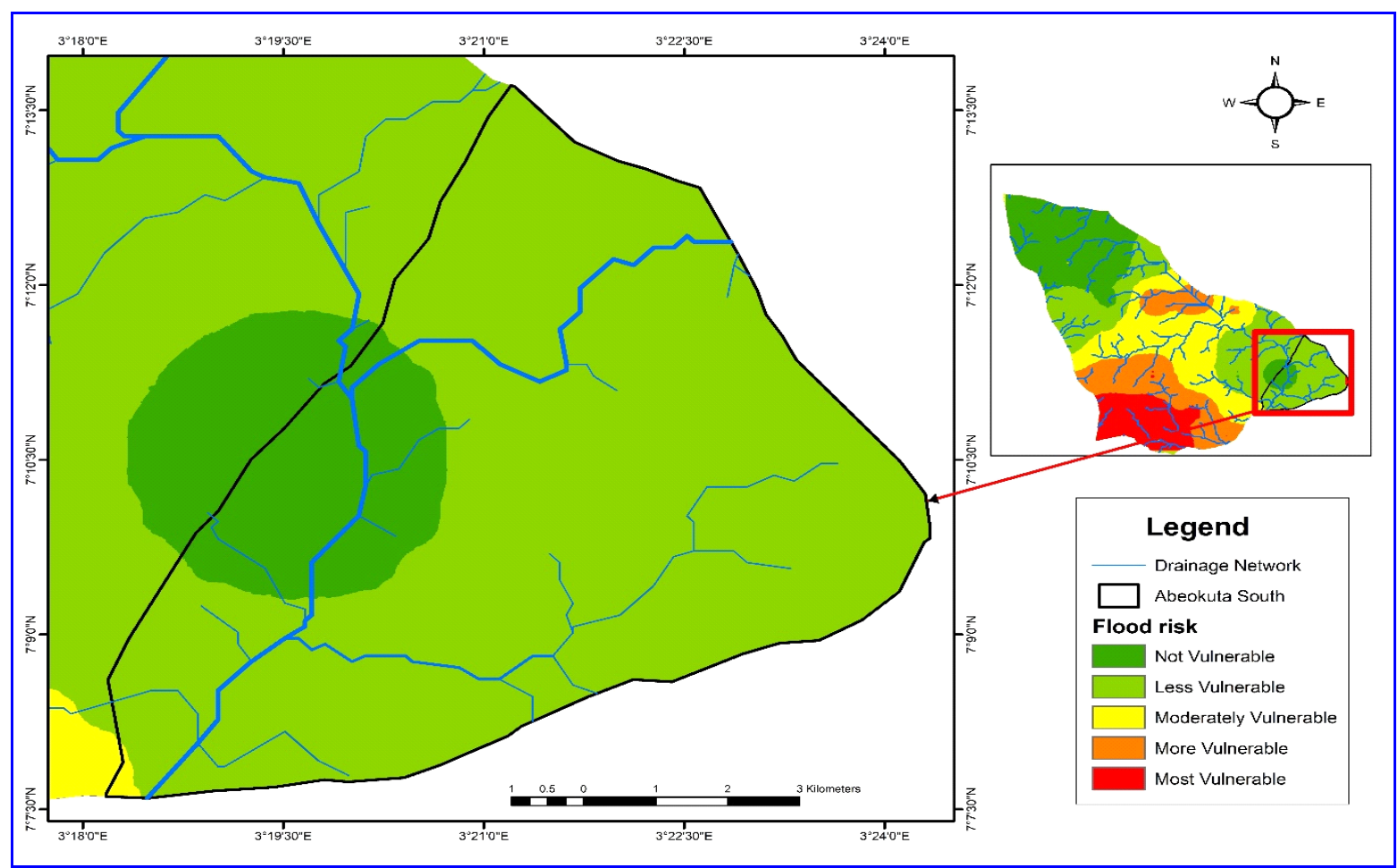

Figure 4: Vulnerability ranking of the study area by rainfall intensity

The map reveals the south western parts of Abeokuta region as the most susceptible to flooding using rainfall as a sole factor in flood vulnerability ranking as shown (red to orange). The populated areas of the region (left) are the least vulnerable. This is however does not exempt the metropolis from flooding particularly when other factors such as soil type, land use and drainage intensities are combined.

\section{b. Flood vulnerability by soil types}

According to FAO classification, Abeokuta city has four soil types namely: Lithosols, Distric Nitosols, Pellic Vertisols and Ferric Luvisols. Distric Nitosols and Ferric Luvisols are the two dominant soil types for Abeokuta-metropolis. While, Distric Nitosols is well drained, Lithosols is moderately drained, Ferric Luvisols is perfectly drained and Pellic Vertisols is poorly drained as presented in Table 5.

Table 5: Area occupied by soil classes in Abeokuta region

\begin{tabular}{lll}
\hline Soil type & Area $\left(\mathrm{km}^{2}\right)$ & Drainage \\
\hline Lithosols & 259.5 & Moderate \\
Distric Nitosols & 437.7 & Well \\
Pellic Vertisols & 0.2 & Poor \\
Ferric Luvisols & 169.7 & Imperfectly \\
\hline
\end{tabular}

Using soil type alone, the northern part of Abeokuta region will be the most susceptible to flooding being the most poorly drained. The persistence of a flooding is determined by soil type (Ponting et al., 2021).

Incidentally, the distribution of the two dominant soil types in Figure 5 reveals the imperfectly drained Ferric Luvisol covering a larger portion of the area occupied by the city metropolis is as shown. With weighting and reclassification, the soil map reveals relative vulnerabilities as shown in Figure 6. 


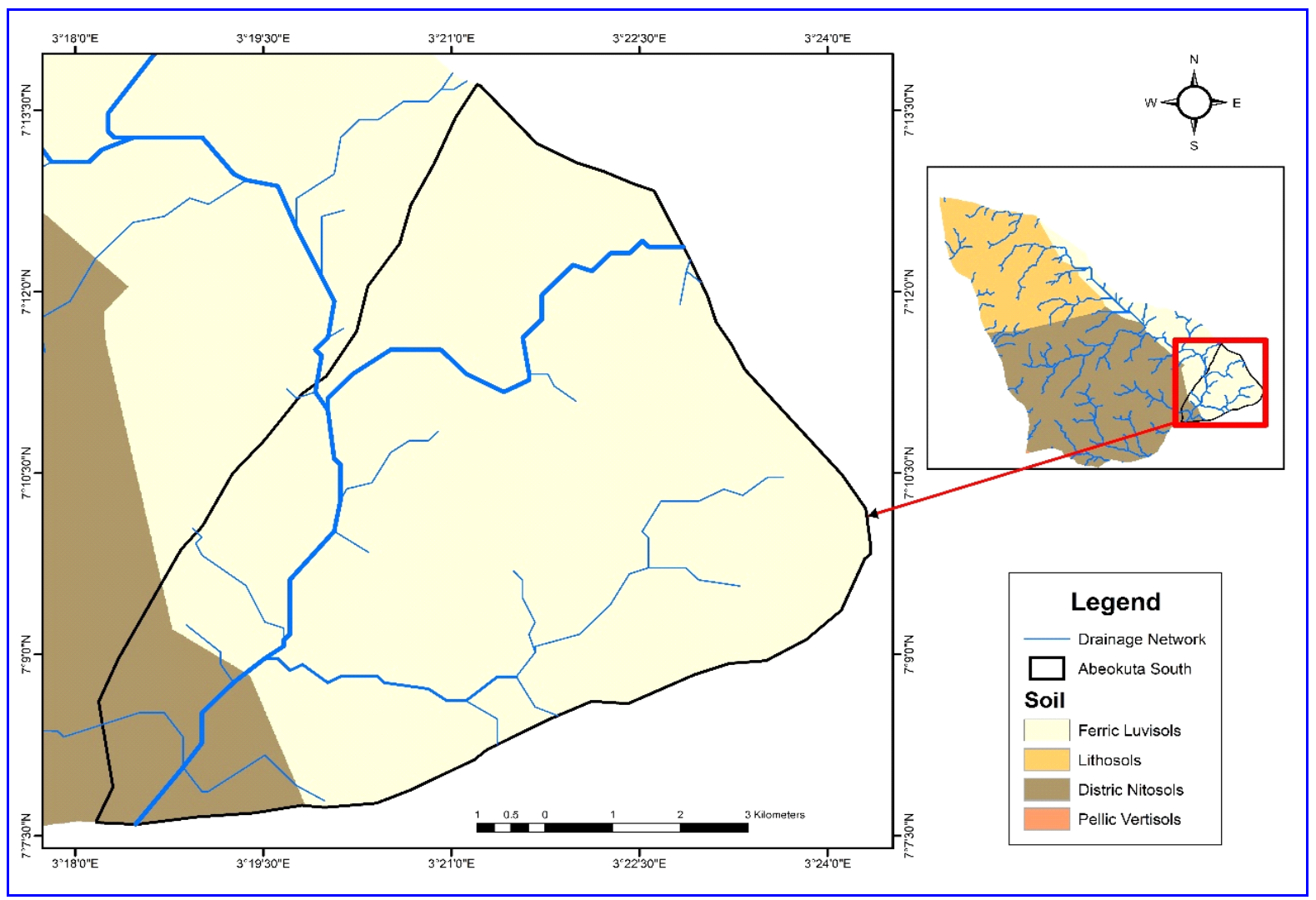

Figure 5: Dominant soils of the study area

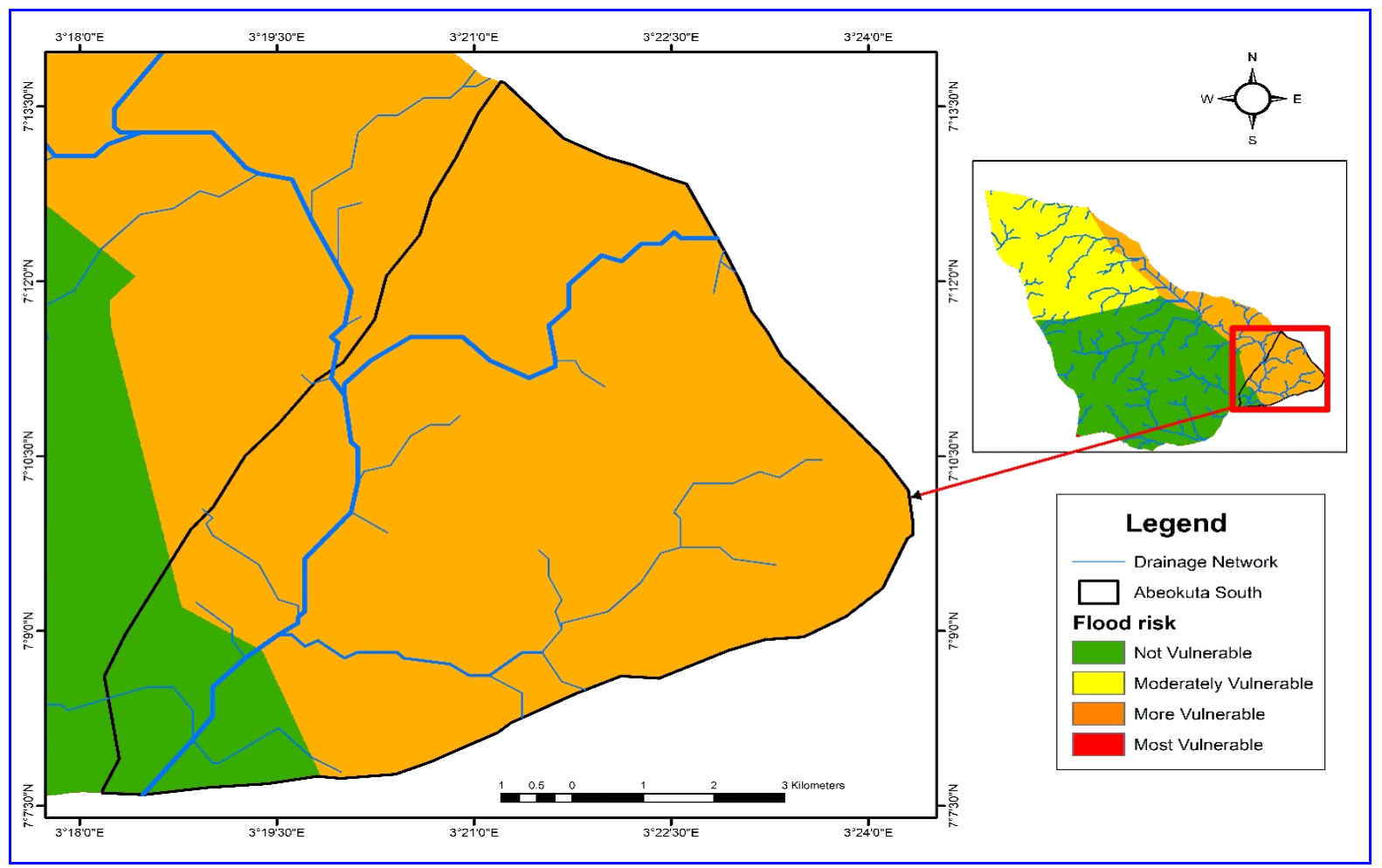

Figure 6: Vulnerability ranking of the study area by soil types

The orange portion of the map portrays most parts of the city as more vulnerable to flooding based on soil characteristics. The most vulnerable portion of the region is occupied by the metropolis as shown.

c. Flood vulnerability by topography

The relief of Abeokuta-South is a mixture of high, low and undulating terrain as shown by the Digital Terrain Model (DTM) in Figure 7. 


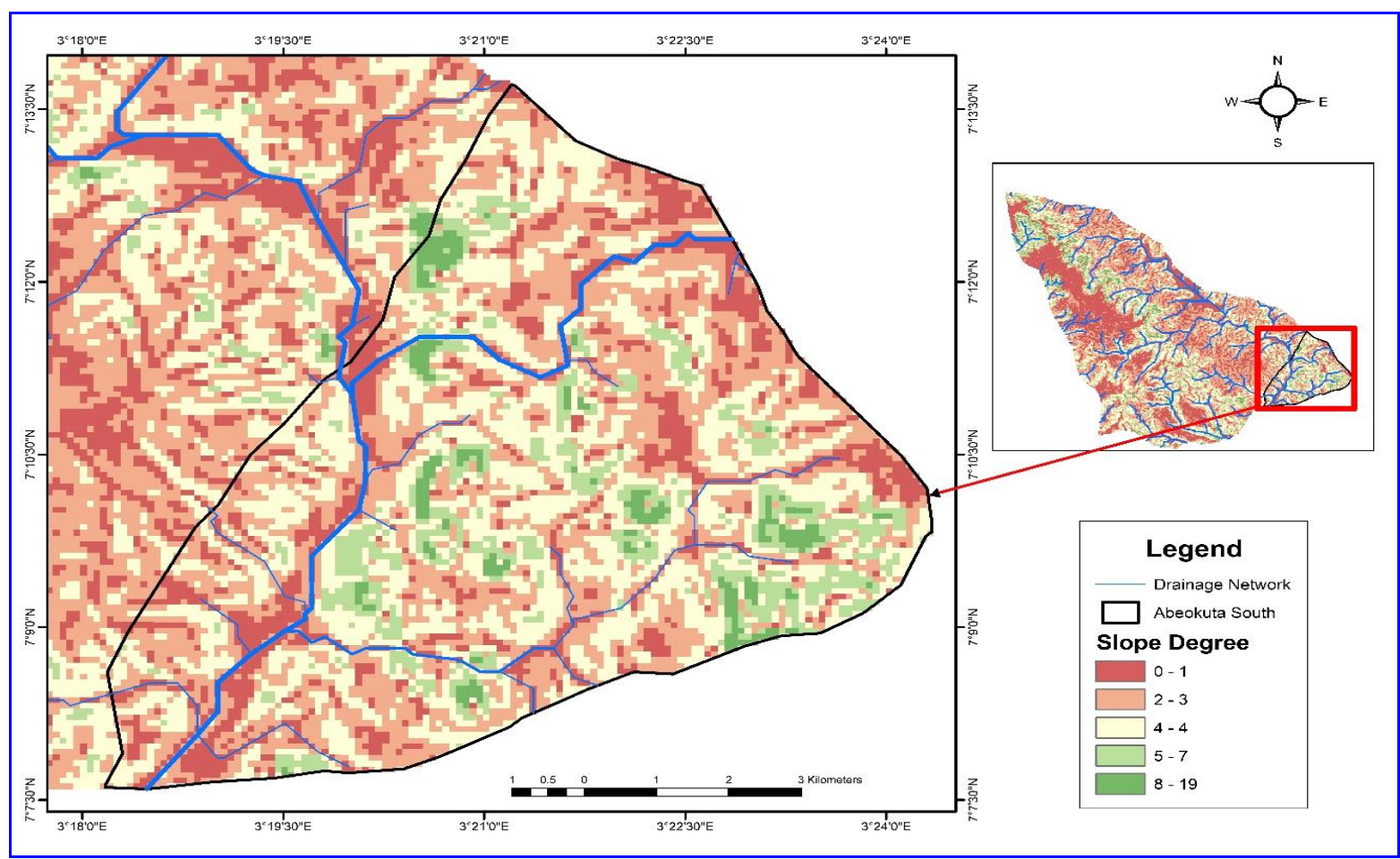

Figure 7: Digital Terrain Model of Abeokuta

The map reveals areas with the steepest slopes (deep to light green) and those with gentle to flat slopes (deep brown to light brown). The areas with almost imperceptible slopes retain more water as the run-off velocities is considerable reduced along the channels and flood plains. The weighted relief presents 5 categories of vulnerability to flooding as shown in Figure 8.

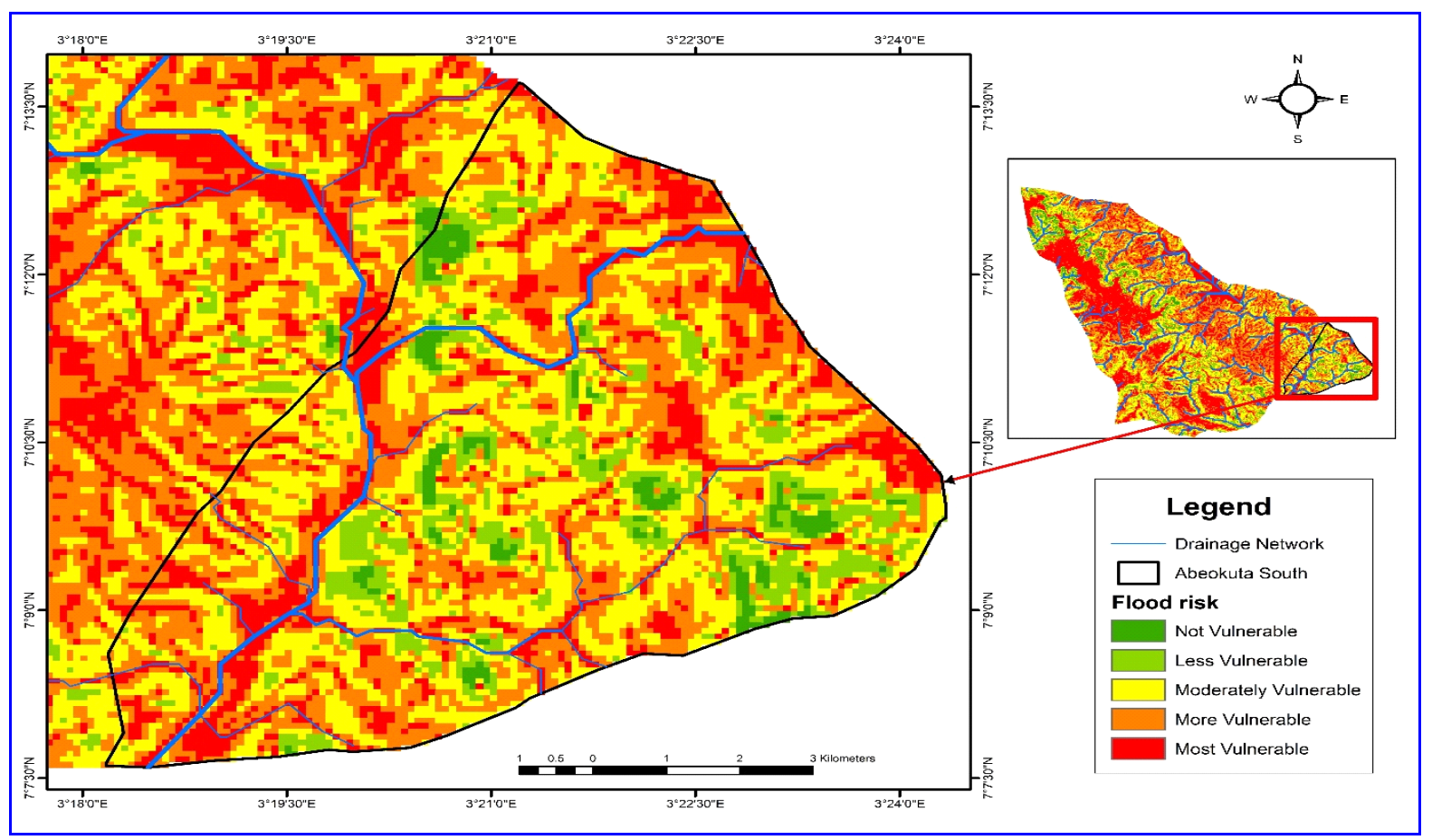

Figure 8: Vulnerability ranking of the study area by topography

The most vulnerable areas (in red) are located along the flood plains of streams and rivers. The areas in yellow are of moderate susceptibility to flooding. A good percentage of the city ranks from more to most vulnerable as shown. Most of the areas coded orange and yellow in the map are actually inland valleys which witness flash flooding annually. Ordinarily, the red-brown zones are natural buffers to the rivers and streams, but they have almost all been built-up. At present they have become locations where the flash flood persists in the city. A recent example is in Plate 1. 

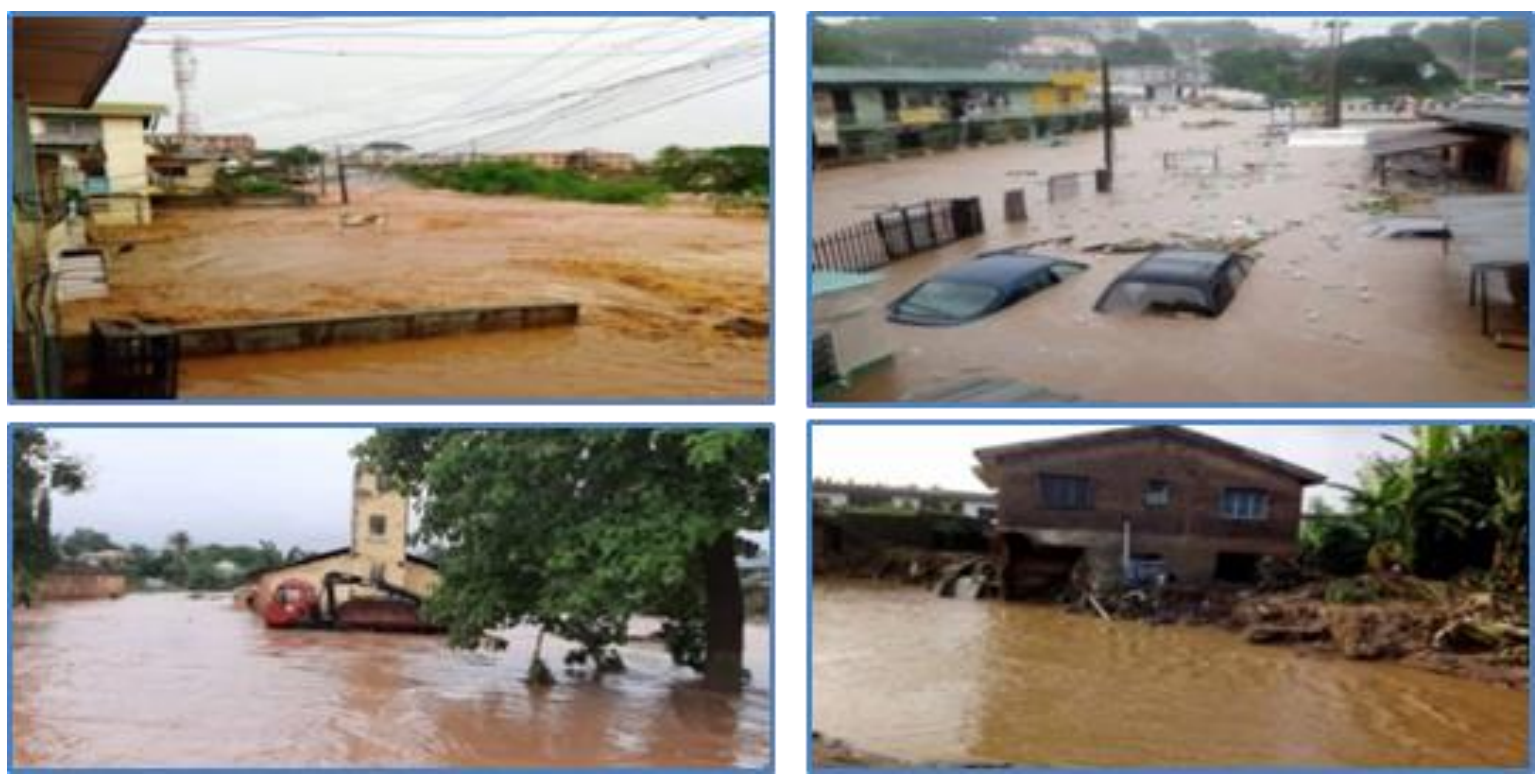

Plate 1 (a-d): Flooding in different parts of Abeokuta Metropolis in April 2020

\section{d. Hydrological Modelling}

The hydrological modelling of the map in Figure 9 reveals that about $48 \%$ of the metropolis is more or highly vulnerable to flooding. This implies that based on topography almost all parts of the metropolis can be flooded as shown.

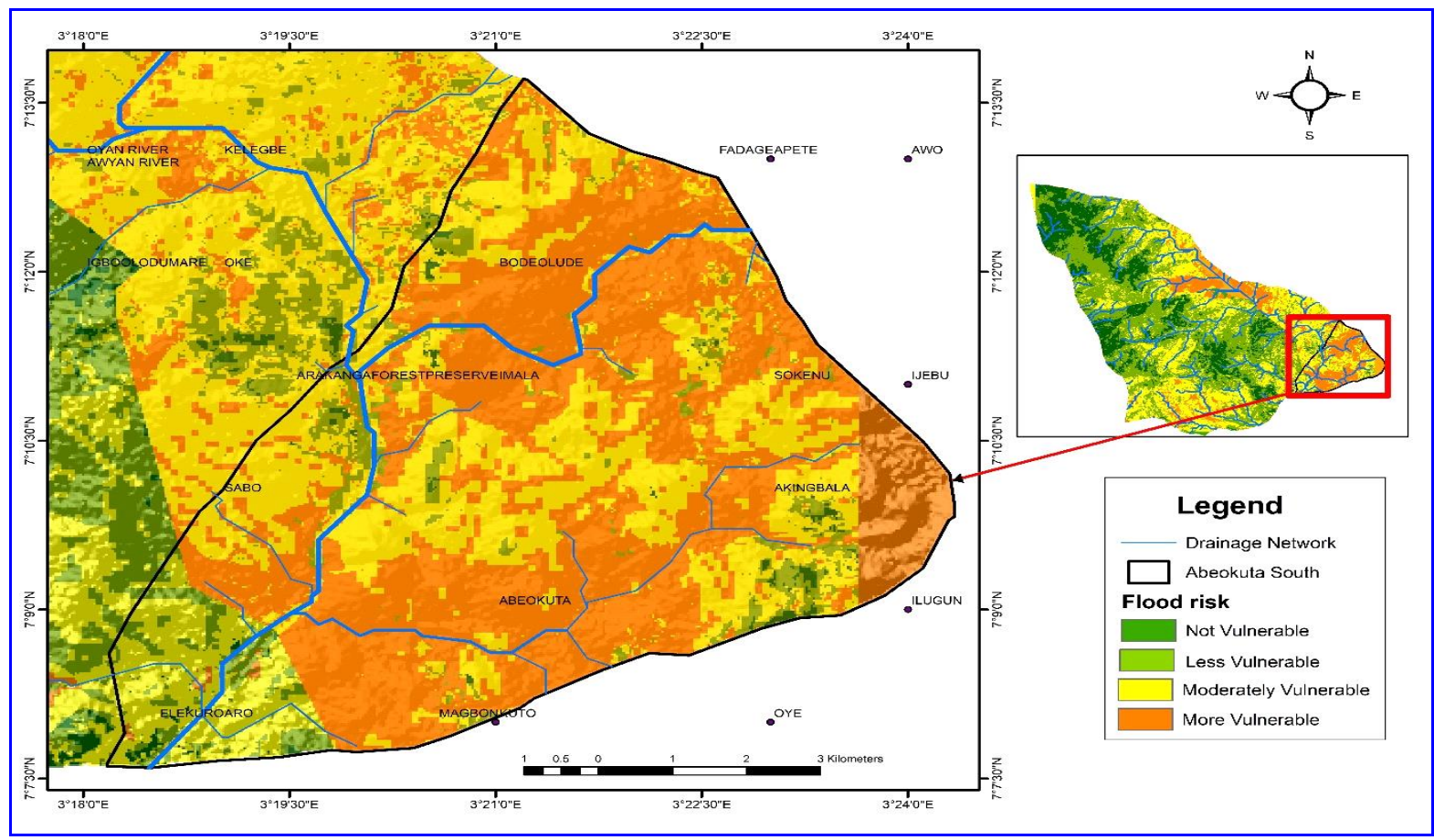

Figure 9: Overall map of vulnerability based on combination of the multiple criteria

\section{e. Flood vulnerability by drainage density}

Drainage density is also a very crucial factor in flooding events. The higher the value of drainage density in an area, the less persistent the flash flood in the area. Drainage density (DD) is given by the equation: $\mathrm{DD}=\mathrm{L} / \mathrm{A}$ in which $\mathrm{L}$ is the total length of drainage channel in $\mathrm{km}$ and $\mathrm{A}$ is the Total area of watershed in $\mathrm{km}^{2}$. The map in Figure 10 shows the GIS computation of drainage density of Abeokuta metropolis. 


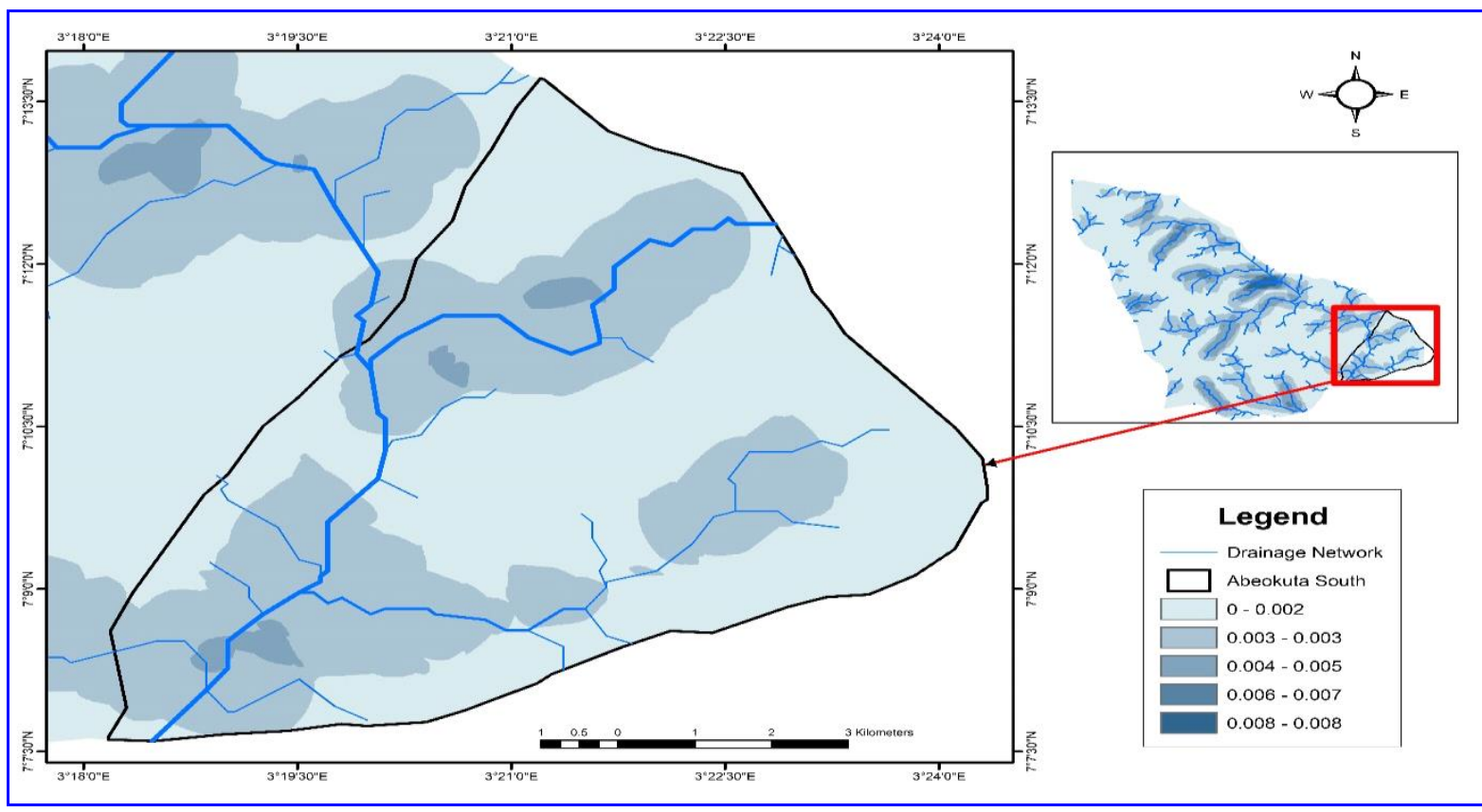

Figure 10: Drainage density of Abeokuta Metropolis (Inset is Abeokuta region)

The darker tone colour tone depicts higher drainage density. The more the density the more susceptible the area is to flooding. Ogun river; the main river in the metropolis has a lot of tributaries. The weighting of the drainage density produced four categories of vulnerability as shown in Figure 11.

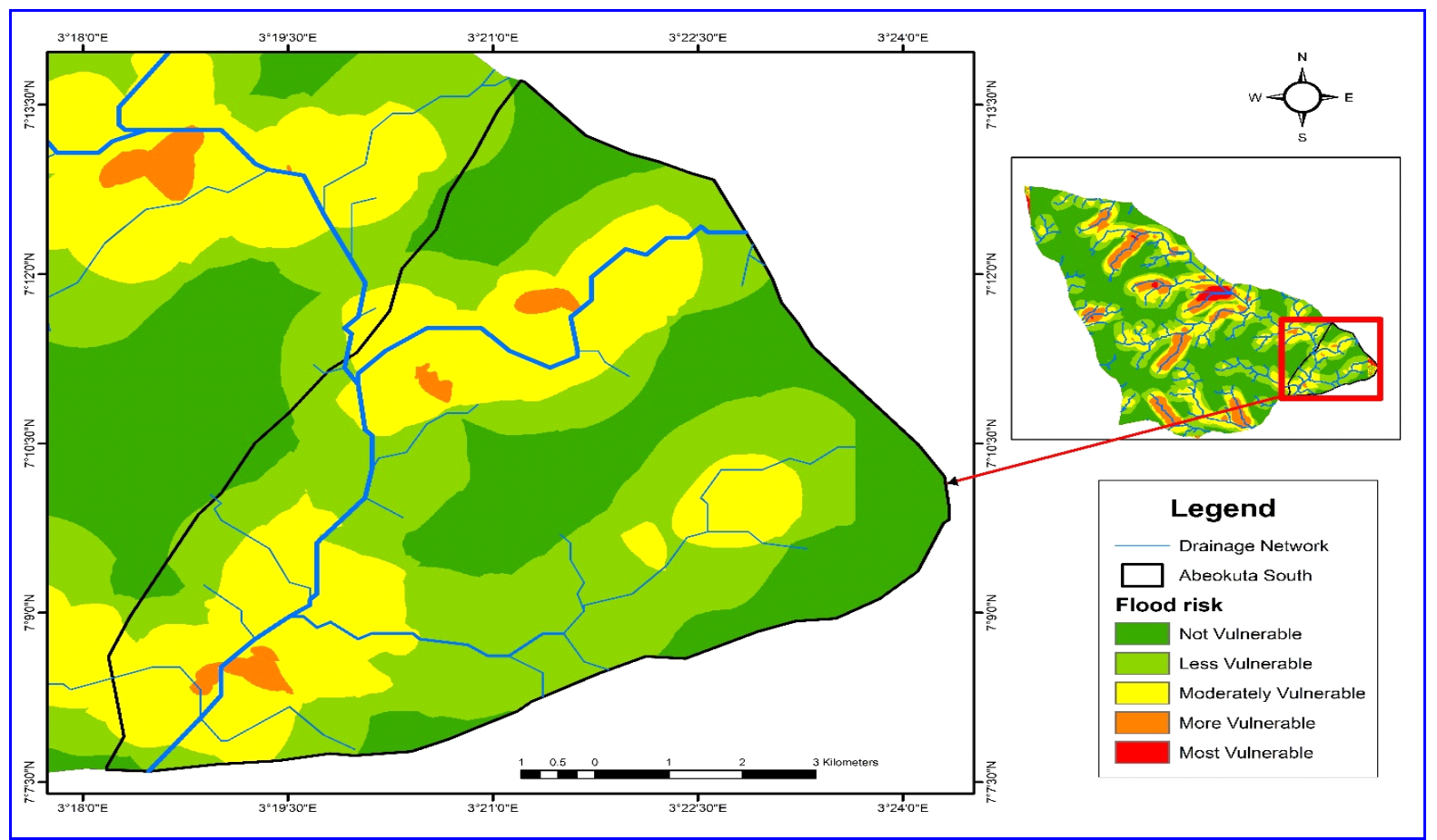

Figure 11: Vulnerability ranking of the study area by drainage density

The most vulnerable areas are around the inland valleys which are often encroached by human buildings as earlier mentioned and depicted in Plate 2. 


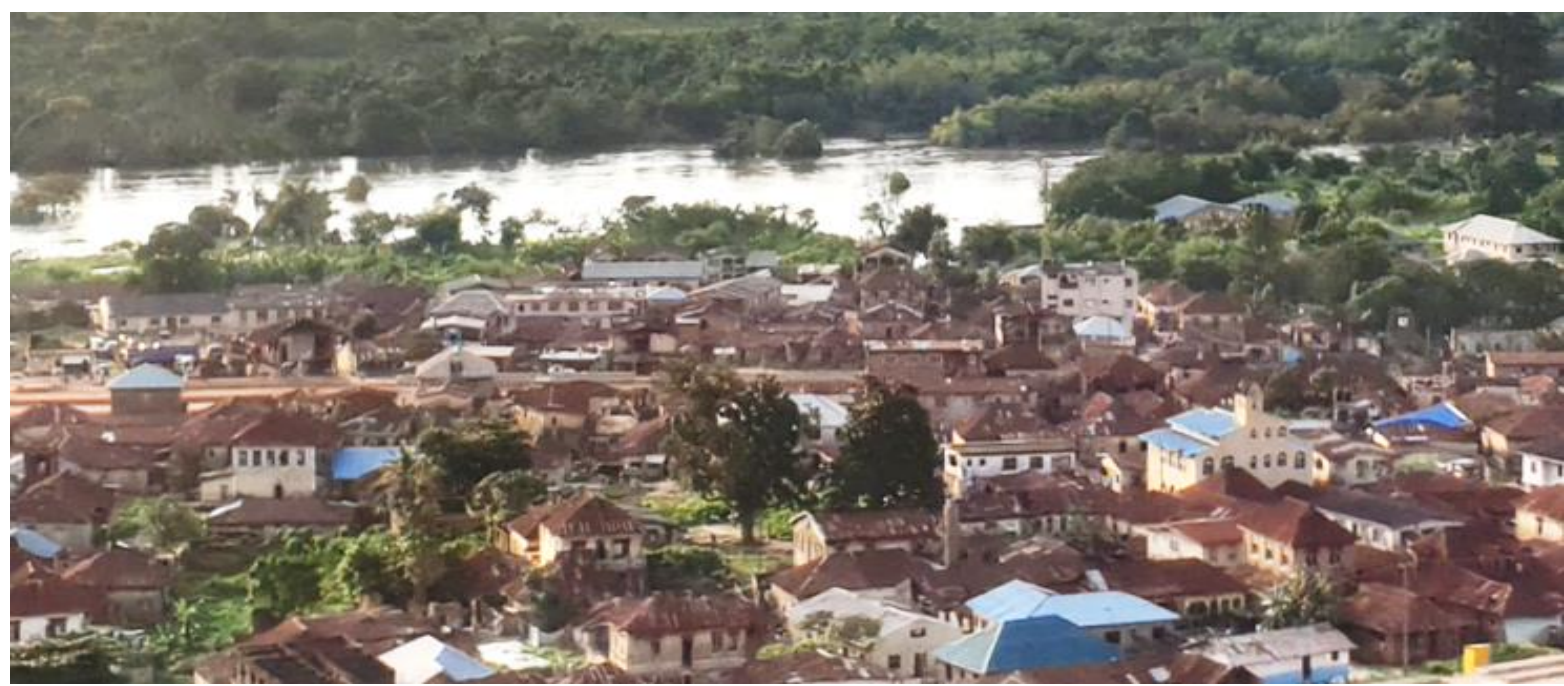

Plate 2: part of Abeokuta city on the flood plain of Ogun River (at the background)

\section{f. $\quad$ Flood vulnerability by land use patterns}

Poor urban planning and land use pattern is a huge predisposing factor to flood disasters. Where the houses are compact and a greater percentage of the grounds are concreted, the tendencies for generating high volume of run-offs are high. Meanwhile, with poor artificial drainage networks, congested areas are easily flooded.

Figure 12 is the land use map of Abeokuta region from which a very massive portion of Abeokuta metropolis (left) is shown as built (comprising of roofed areas and concretized grounds).

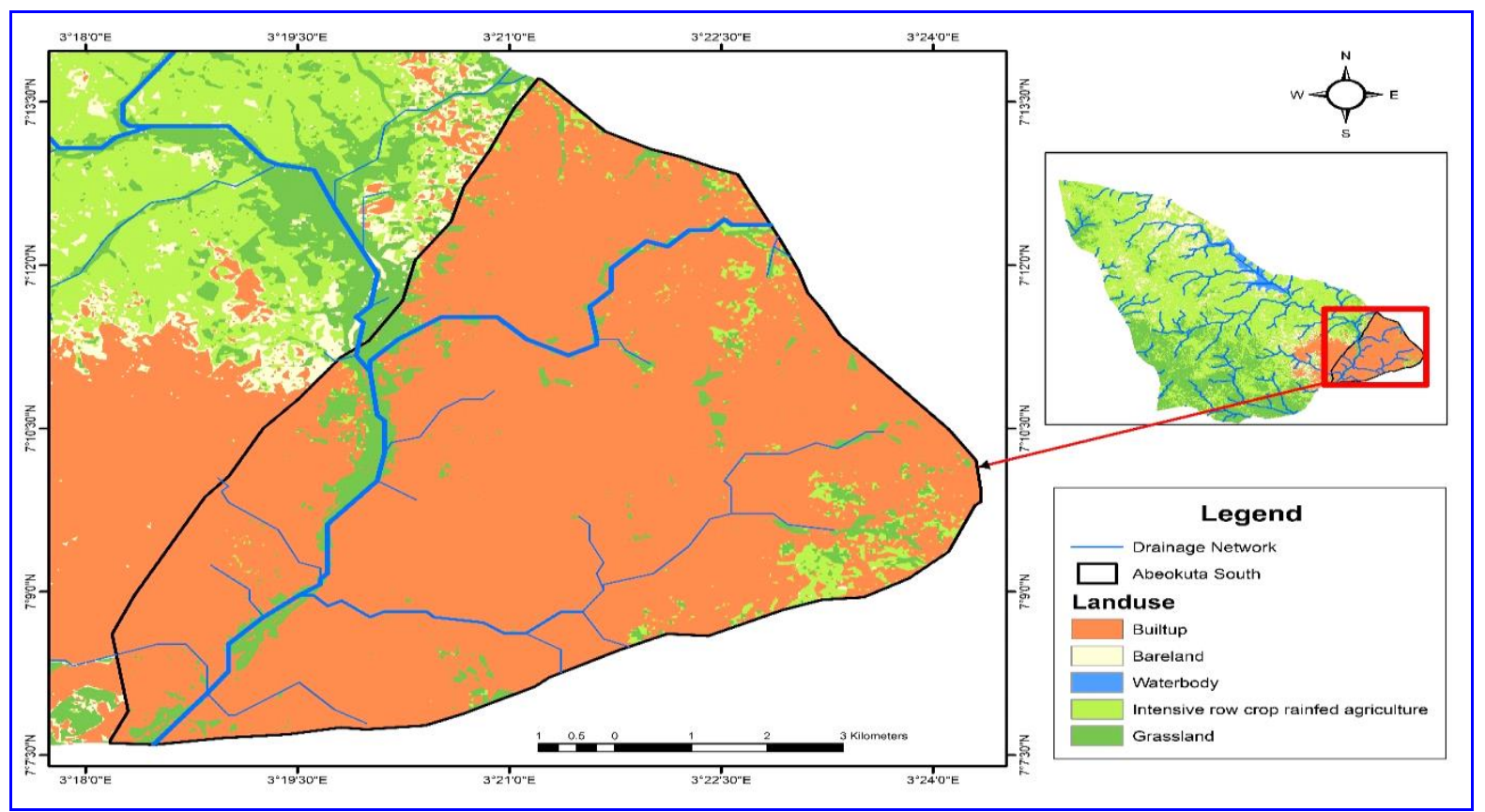

Figure 12: General Land use types of Abeokuta

The map shows very sparse portion of the area occupied by the metropolis as vegetated. Where the constructed channels are blocked by debris or have become too narrow to contain the high volume of run-off from the city, the flood appears in the inland valleys which incidentally have become occupied by residential and other human structures. Further to this is the fact that changes in land use associated with urbanization also contributes to flooding. For instance, construction of roads, schools or factories often remove vegetation, causing free flow of run-offs, soil erosion and creation of depressions on the land surface. When permeable soil is replaced by impermeable surface, reduction in water percolation and consequently flooding occurs. 
The land use types of Abeokuta metropolis include: Built up, Water bodies, Grassland, rain-fed Agriculture and Bare-land. Assigning weights to the land use types shows five levels of susceptibility to flooding as shown in the vulnerability map in Figure 13.

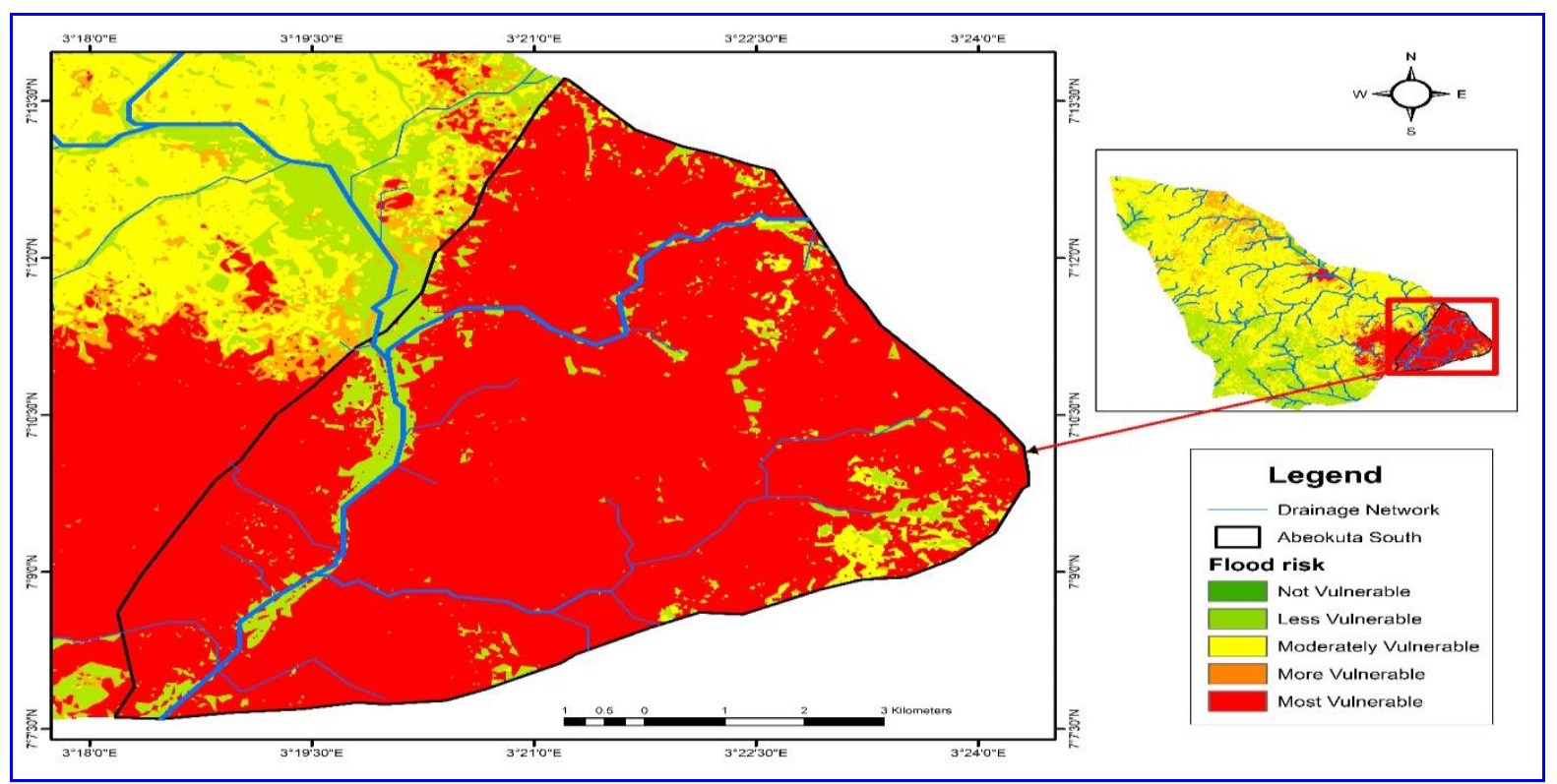

Figure 13: Vulnerability ranking of the study area by drainage density

With respect to land use types, most parts of the city (in red) are highly vulnerable since large part of the area is built up.

\section{g. Flood vulnerability by a combination of contributing factors}

It may be slightly difficult to take decision on the relative vulnerabilities of the various parts of the city by independent consideration of the respective factors of flooding considered in this study. A combination of the factors is always useful for spatial decision support.

In Figure 14 is the result of the combination of the multiple criteria.

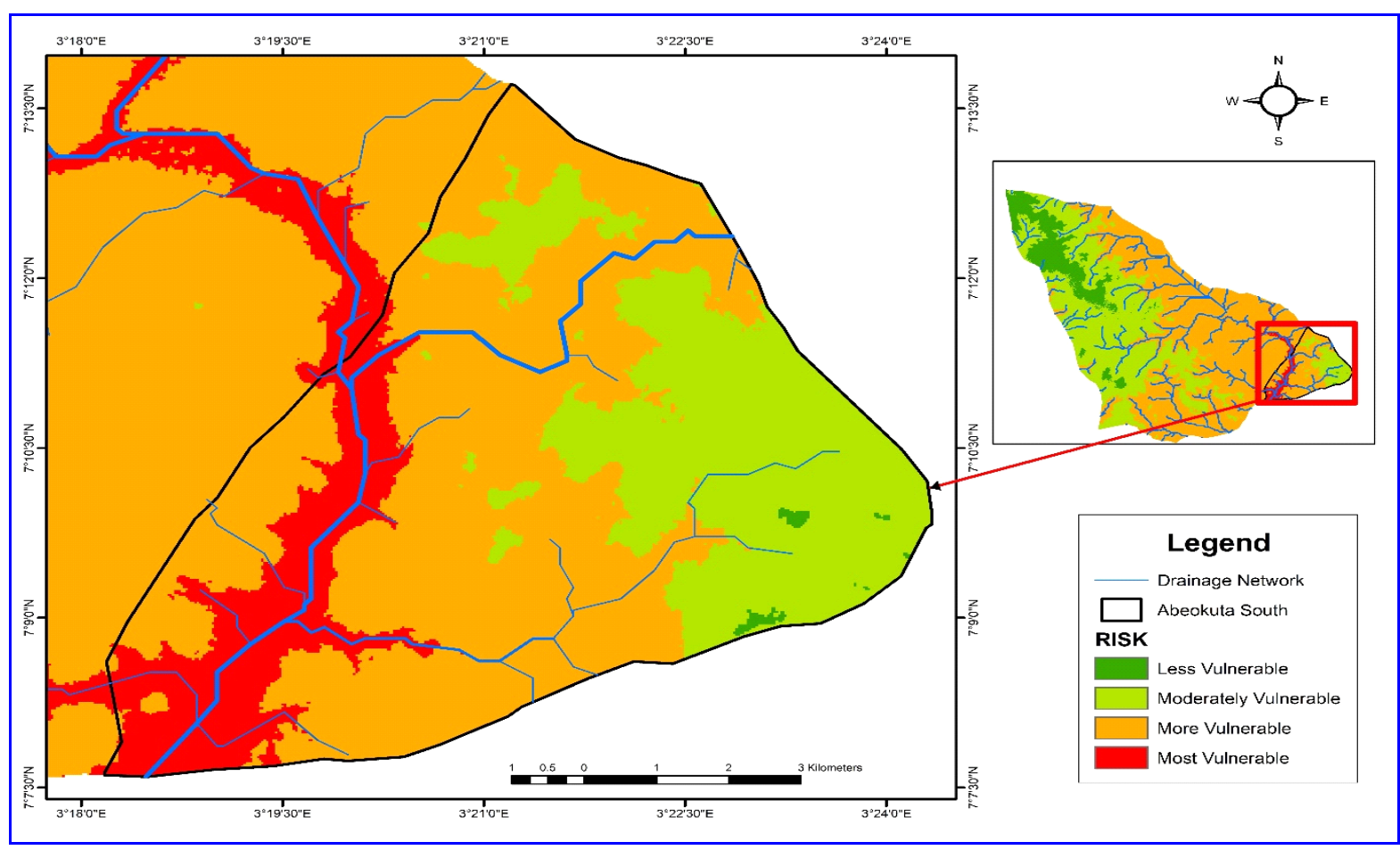

Figure 14: Overall map of vulnerability based on combination of the multiple criteria 
The map shows the flood plains as the most vulnerable to flooding and next to it is a large portion all around the flood plains. Although no area upland is in the red zone but almost half of the metropolis are still highly vulnerable to flood events especially along streams and rivulets within the townships.

Figure 14 becomes a spatial decision support tool if the nearness to the sources of flooding is examined. For example, with a setback of 500 meters from the rivers and flood plains, it is possible to determine. The result shows areas that are more vulnerable to flooding are within a distance of 500 meters from the river. These areas are likely to be the mostly impacted in the event of flooding.

Figure 15 gives the picture of the $500 \mathrm{~m}$ zone of influence with regards to flash flood. All structures within these zones should be inspected and ensured that they would be safe in the event of flood.

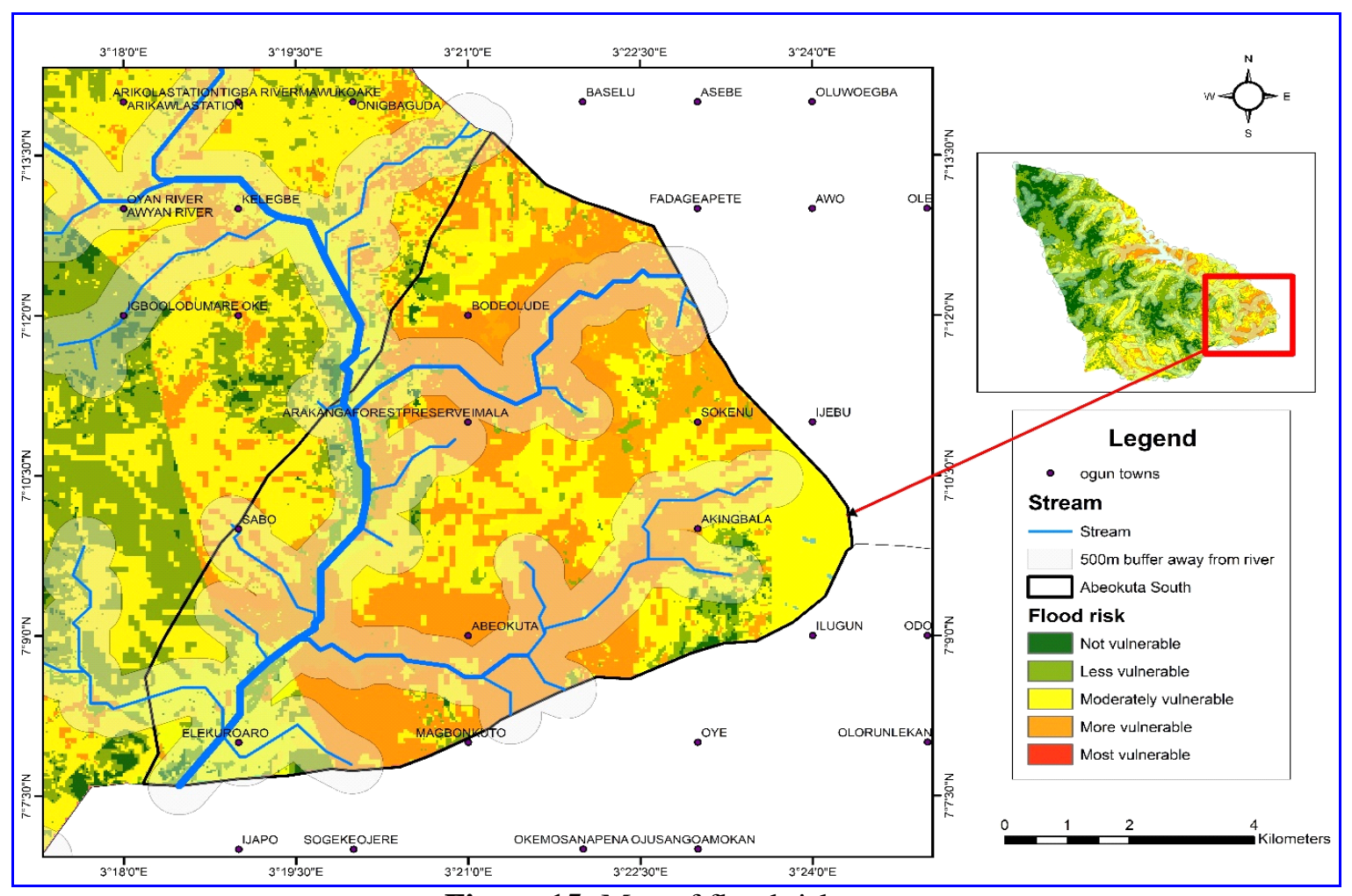

Figure 15: Map of flood risk zone

The various phases of analysis carried out have given an in-depth understanding of the areas that are vulnerable to flood within Abeokuta metropolis and the factor that has played the major role in predisposing the city to deluge. This insight pre-empts the recommendations of the study on how flood could be effectively controlled and managed. The key findings are documented in the conclusion.

\subsection{Conclusion}

Weighted linear combination procedures using remote sensing and Geospatial techniques was reliable in the determination of areas vulnerable to flooding across Abeokuta region. The city is less vulnerable with regards rainfall intensity, but the soil in most part of the city Ferric Luvisol; which are poorly drained and as such by soil type almost the entire metropolis is susceptible to flooding. The city relief also show a lot of inland valleys and high drainage density both factors influences flooding. Another predisposing factor is the compact nature of the settlement pattern; the city is compact and most building roofs and concreted premises contribute to the volume of run offs. Most importantly, several buildings are sited within the inland valleys. The overall result of the analysis shows that the flood plains and inland valleys are the most vulnerable to flooding and next to it is the large portion of the landscape surrounding the flood plains. Although no area upland is in the red zone but almost half of the metropolis are still highly vulnerable to flood events especially along streams and rivulets within the townships. The study identified topography and land use as key factors contributing to 
flooding within Abeokuta metropolis. Obstructions of natural drainage channels by buildings can aggravate disasters from flash flood events.

\section{References}

Aderogba, K. A., Oredipe, M., Oderinde, S. and Afelumo, T. (2012). Challenges of poor drainage systems and floods in Lagos Metropolis, Nigeria. International J. Soc. Sci. \& Education, 2(3), pp. 412-427.

Akinse, A. G. and Gbadebo, A. M. (2016). Geologic Mapping of Abeokuta Metropolis, Southwestern Nigeria. International Journal of Scientific \& Engineering Research, 7(8), pp. 979-983.

Akinyemi, D. F., Ayanlade, O. S., Nwaezeigwe, J. O. and Ayanlade, A. (2020). A Comparison of the Accuracy of Multi-Satellite Precipitation Estimation and Ground Meteorological Records Over Southwestern Nigeria. Remote Sens Earth Syst Sci, 3, pp. 1-12.

Al-Hanbali, A. (2011). Using GIS-Based Weighted Linear Combination Analysis and Remote Sensing Techniques to Select Optimum Solid Waste Disposal Sites within Mafraq City, Jordan Journal of Geographic Information System, 3(04), pp. 267-278. DOI: 10.4236/jgis.2011.34023

BBC News (2018). Why does Nigeria keep flooding? Online news article available at https://www.bbc.com/news/world-africa-45599262 Reality Check team Published 26 September 2018, Retrieved 2 September 2020.

Chen, S., Liu, H., You, Y., Mullens, E., Hu, J,, Yuan, Y., Huang, M., He, L., Luo, Y., Zeng, X., Tang, Y., Hong, Y. et al. (2014) Evaluation of High-Resolution Precipitation Estimates from Satellites during July 2012 Beijing Flood Event Using Dense Rain Gauge Observations. PLoS ONE 9(4): e89681. doi:10.1371/journal.pone.0089681

Cirella, G. T. and Iyalomhe, F. O. (2018). Flooding Conceptual Review: Sustainability-Focalized Best Practices in Nigeria. Appl. Sci. 8, pp. 1558. https://doi.org/10.3390/app8091558

Dewan, A. M. (2013). Floods in a Megacity: Geospatial Techniques in Assessing Hazards, Risk and Vulnerability. Springer Publication, Netherlands. 199p http://dx.doi.org/10.1007/978-94-007-5875-9

Djimesah, I. E., Okine, A.N.D. and Mireku, K. K. (2018). Influential factors in creating warning systems towards flood disaster management in Ghana: An analysis of 2007 Northern flood. International Journal of Disaster Risk Reduction, 28, pp. 318-326.

Echendu, A. J. (2020). The impact of flooding on Nigeria's sustainable development goals (SDGs), Ecosystem. Health and Sustainability, 6(1), pp. 1-13. https://doi.org/10.1080/20964129.2020.1791735

Efobi, K. (2013). Urban Flooding and Vulnerability of Nigerian Cities: A Case Study of Awka and Onitsha in Anambra State, Nigeria. Journal of Law, Policy and Globalization, 19, pp. 58-64.

Egbinola, C. N., Olaniran, H. D. and Amanambu, A. C. (2017). Flood management in cities of developing countries: the example of Ibadan, Nigeria. J. Flood risk management, 10, pp. 546-554.

Elsheikh, R. F. A., Ouerghi, S. and Elhag, A. R. (2015). Flood Risk Map Based on GIS, and Multi Criteria Techniques (Case Study Terengganu Malaysia). Journal of Geographic Information System, 7, pp. 348-357.

Fernandez, P., Mourato, S. and Moreira, M. (2016). Social vulnerability assessment of flood risk using GIS-based multi-criteria decision analysis. A case study of Vila Nova de Gaia (Portugal). Geomatics, Natural Hazards and Risk, 7(4), pp. 1367-1389.

Floodlist (2020). Nigeria. Online flood news articles available at http://floodlist.com/tag/nigeria 
Halgamuge, M. N. and Nirmalathas, A. (2017). Analysis of large flood events: Based on flood data during 1985-2016 in Australia and India. International Journal of Disaster Risk Reduction, 24, pp. 111.

Hong, M., Kim, J. and Jeong, S. (2018). Rainfall intensity-duration thresholds for landslide prediction in South Korea by considering the effects of antecedent rainfall. Landslides, 15, pp. 523-534.

Hu, P., Zhang, Q., Shi, P., Chen, B. and Fang, J. (2018). Flood-induced mortality across the globe: Spatiotemporal pattern and influencing factors. Science of the Total Environment, 643, pp. 171-182.

Komolafe, A. A., Awe, B. S., Olorunfemi, I. E. and Oguntunde, P. G. (2020). Modelling flood-prone area and vulnerability using integration of multi-criteria analysis and HAND model in the Ogun River Basin, Nigeria. Hydrological Sciences Journal, 65(10), pp. 1766-1783.

Mahmoody, V. N. and Jelokhani-Niaraki, M. (2021). The use of subjective-objective weights in GISbased multi-criteria decision analysis for flood hazard assessment: a case study in Mazandaran, Iran. GeoJournal, 86, pp. 379-398. https://doi.org/10.1007/s10708-019-10075-5

Martinez, M., Bakheet, R. and Akib, S. (2021). Innovative Techniques in the Context of Actions for Flood Risk Management: A Review. Eng, 2, pp. 1- 11. https://dx.doi.org/10.3390/ eng2010001

Mekong River Commission (MRC, 2016). Manual on Flood Preparedness Program for Provincial and District Level Authorities in the Lower Mekong Basin Countries. 26p https://www.preventionweb.net/files/13076_Flood09.pdf

Moeinaddini, M., Khorasani, N., Danehkar, A., Darvishsefat, A. A., and Zienalyan, M. (2010). Siting MSW landfill using weighted linear combination and analytical hierarchy process (AHP) methodology in GIS environment (case study: Karaj). Waste Management, 30(5), pp. 912-920.

Morales, F. F. and de Vries, W. T. (2021). Establishment of Natural Hazards Mapping Criteria Using Analytic Hierarchy Process (AHP). Front. Sustain. 2, 667105p. doi: 10.3389/frsus.2021.667105

Nasiri, H., Mohd Yusof, M.J. and Mohammad Ali, T.A. (2016). An overview to flood vulnerability assessment methods. Sustain. Water Resour. Manag. 2, pp. 331-336. https://doi.org/10.1007/s40899016-0051-x

Nasiri, H., Yusof, M. J. M. and Ali, T. A. M. (2019). District flood vulnerability index: urban decision-making tool. Int. J. Environ. Sci. Technol. 16, pp. 2249-2258.

Nazeer, M. and Bork, H. (2019). Flood Vulnerability Assessment through Different Methodological Approaches in the Context of North-West Khyber Pakhtunkhwa, Pakistan. Sustainability, 11, 6695p, doi:10.3390/su11236695 www.mdpi.com/journal/sustainability

Nkeki, F. N., Henah, P. J. and Ojeh, V. N. (2013). Geospatial Techniques for the Assessment and Analysis of Flood Risk along the Niger-Benue Basin in Nigeria. Journal of Geographic Information System, 5(2), pp. 123-135. DOI: 10.4236/jgis.2013.52013.

Ogbonna, D. N., Amangabara, G. T. and Itulua, P. A. (2011). Study of the nature of urban flood in Benin City, Edo State, Nigeria. Global Journal of Pure and Applied Sciences, 17(1), pp. 7-21.

Ogunaike, J. (2020). Flood destroys part of Obasanjo Library Fence. An article in Vanguard a Nigerian daily newspaper also available on line at https://www.vanguardngr.com/2020/07/photosflood-destroys-part-of-obasanjo-library-fence/

Ogundele, O. M. and Ubaekwe, R. E. (2019). Early Warning System and Ecosystem-Based Adaptation to Prevent Flooding in Ibadan Metropolis, Nigeria. In: Leal Filho W. (eds) Handbook of Climate Change Resilience. Springer, Cham. https://doi.org/10.1007/978-3-319-71025-9 112-1 
Olanrewaju, C. C., Chitakira, M., Olanrewaju, O. A. and Louw, E. (2019). Impacts of flood disasters in Nigeria: A critical evaluation of health implications and management. Jamba (Potchefstroom, South Africa), 11(1), 557p. https://doi.org/10.4102/jamba.v11i1.557

Olawuni, O.P., Popoola, A.S., Bolukale, A.T., Eluyele, K. P. and Adegoke, J. O. (2015)

An Assessment of the Factors Responsible for Flooding in Ibadan Metropolis, Nigeria. Journal of Environment and Earth Sciences, 5(21): 1-7.

Perera, D., Seidou, O., Agnihotri, J., Rasmy, M., Smakhtin, V., Coulibaly, P., et al. (2019). Flood Early Warning Systems: A Review of Benefits, Challenges and Prospects. UNU-INWEH Report Series, Issue 08. United Nations University Institute for Water, Environment and Health, Hamilton, Canada. http://inweh.unu.edu/publications/ ISBN: 978-92-808-6096-2

Ponting, J., Kelly, T. J., Verhoef, A., Watts, M. J. and Sizmur, T. (2021). The impact of increased flooding occurrence on the mobility of potentially toxic elements in floodplain soil. Science of the Total Environment, 754 (2021), 142040p. https://doi.org/10.1016/j.scitotenv.2020.142040

Population Stat (2020). Abeokuta, Nigeria, Population. https://populationstat.com/nigeria/abeokuta Accessed on October, 15th, 2020

Rimba, A. B., Setiawati, M. D., Sambah, A. B. and Miura, F. (2017). Physical Flood Vulnerability Mapping: Applying Geospatial Techniques in Okazaki City, Aichi Prefecture, Japan. Urban Sci. 2017(1), 7p. https://doi.org/10.3390/urbansci10100077

Rubinato, M., Nichols, A., Peng, Y., Zhang, J., Lashford, C., Cai, Y., et al. (2019). Urban and river flooding: Comparison of flood risk management approaches in the UK and China and an assessment of future knowledge needs. Water Science and Engineering, 12(4), pp. 274-283.

Sobowale, A. and Oyedepo, J. A. (2013). Status of flood vulnerability area in an ungauged basin, South-west Nigeria. International Journal of Agricultural and Biological Engineering, 6(2), pp. 2836. DOI: $10.3965 /$ j.ijabe.20130602.004

Siddayao, G. P., Valdez, S. E., and Fernandez, P. L. (2014). Analytic Hierarchy Process (AHP) in Spatial Modeling for Floodplain Risk Assessment. International Journal of Machine Learning and Computing, 4(5), pp. 450-457. DOI: 10.7763/IJMLC.2014.V4.453

Špitalar, M., Brilly, M., Kos, D. and Žiberna, A. (2020). Analysis of Flood Fatalities-Slovenian Illustration. Water, 12(1), pp. 64-78,https://doi.org/10.3390/w12010064

Tanoue, M., Hirabayashi, Y. and Ikeuchi, H. (2016). Global-scale river flood vulnerability in the last 50 years. Scientific reports, 6, 36021p. https://doi.org/10.1038/srep36021

Tascón-González, L., Ferrer-Julià, M., Ruiz, M. and García-Meléndez, E. (2020). Social Vulnerability Assessment for Flood Risk Analysis. Water, 12, 558p, doi:10.3390/w12020558

Tzioutzios, C. and Kastridis, A. (2020). Multi-Criteria Evaluation (MCE) Method for the Management of Woodland Plantations in Floodplain Areas. ISPRS Int. J. Geo-Inf. 2020(9), 725p. https://doi.org/10.3390/ijgi9120725

United Nations Office for Disaster Risk Reduction (UNISDR, 2015) UNISDR annual report 2015. 75 p. https://www.undrr.org/publications

Umaru, E. T. and Adedokun, A. (2020). Geospatial Analysis of Flood Risk and Vulnerability Assessment along River Benue Basin of Kogi State. Journal of Geographic Information System, 12, pp. 1-14. DOI: 10.4236/jgis.2020.121001

Wang, Y., Fang, Z., Hong, H. and Peng, L. (2019). Flood susceptibility mapping using convolutional neural network frameworks. Journal of Hydrology, 124482p. doi:10.1016/j.jhydrol.2019.124482 
Wang, Y., Li, Z., Tang, Z. and Zeng, G. (2011). A GIS-Based Spatial Multi-Criteria Approach for Flood Risk Assessment in the Dongting Lake Region, Hunan, Central China. Water Resources Management, 25(13), pp. 3465-3484. doi:10.1007/s11269-011-9866-2

Zorn, M. (2018). Natural Disasters and Less Developed Countries. In: Nature, Tourism and Ethnicity as Drivers of (De) Marginalization, Pelc, S. and Koderman, M. (Eds)., pp. 59-78. Springer international publishing

\section{Cite this article as:}

Oyedepo J. A., Adegboyega J., Oluyege D. E. and Babajide, E. I. 2021. Weighted linear combination procedures with GIS and remote sensing in Flood Vulnerability analysis of Abeokuta metropolis in Nigeria. Nigerian Journal of Environmental Sciences and Technology, 5(1), pp. 240-257. https://doi.org/10.36263/nijest.2021.01.0260 